\title{
Wybrane zagadnienia z problematyki rozwoju obszarów wiejskich, płatności bezpośrednich w orzecznictwie sądów administracyjnych
}

\section{Uwagi ogólne}

Wśród czynników mających wpływ na kierunki rozwoju prawa rolnego wskazuje się - w zależności od zastosowanego kryterium podziału - na czynniki: krajowe, wspólnotowe i międzynarodowe, a mając na uwadze dziedziny życia, których dotyczą - na czynniki: polityczne, gospodarcze czy prawne. ${ }^{1}$ Niewątpliwie orzecznictwo sądowe nie należy do tych pierwszoplanowych czynników, które wyznaczałoby nowe tendencje i kierunki rozwoju w prawie rolnym. Stanowi jednak czynnik, który w sposób pośredni oddziaływuje na kierunki rozwoju prawa rolnego. Orzecznictwo sądowe, w szczególności orzecznictwo sądów administracyjnych stanowi bowiem nie tylko kontrolę działalności organów administracji z punktu widzenia zgodności z prawem, ale $\mathrm{w}$ granicach wyznaczonych przez prawo obejmuje również kontrolę obowiązującego porządku prawnego z punktu widzenia zgodności z ustawami i zasadami konstytucyjnymi, czy to poprzez kierowanie pytań do Trybunału Konstytucyjnego, czy też poprzez odmowę zastosowania aktu wykonawczego w przypadku jego niezgodności z ustawą. Można zatem powiedzieć, że ukształtowane w wyniku wpływu różnorodnych czynników normy prawa rolnego poddane zostają w orzecznictwie sądowym ostatecznej ich weryfikacji. Ta weryfikacja, przeprowadzana drogą orzecznictwa sądowego, a szczególnie orzecznictwa sądów administracyjnych, pozwala zarówno na dokonanie wykładni stosowanych przepisów prawa, ale równocześnie wskazuje na niedoskonałości obowiązującego prawa, prowadząc niejednokrotnie w sposób pośredni do jego zmiany. Tym samym orzecznictwo sądowe jest jednym z czynników, które wpływa na kształt i rozwój prawa rolnego. 


\section{Problematyka rozwoju obszarów wiejskich}

\section{Płatności dla gospodarstw niskotowarowych}

W kilku sprawach rozpatrywanych przez Wojewódzki Sąd Administracyjny w Krakowie, a dotyczących przyznania płatności dla gospodarstw niskotowarowych, pojawił się niezmiernie interesujący problem dotyczący definicji gospodarstwa rolnego, a konkretnie kryterium obszarowego, jakie musi spełniać gospodarstwo rolne, aby z tej formy pomocy można było skorzystać. Dla rozstrzygnięcia powyższej kwestii koniecznym stało się rozważenie charakteru prawnego Planu Rozwoju Obszarów Wiejskich, a konkretnie czy plan ten może stanowić źródło prawa.

Mianowicie w sprawie sygn. akt III SA/Kr 1403/06 (podobnie w sprawie sygn. akt III SA/Kr 498/06) Dyrektor Małopolskiego Oddziału Regionalnego Agencji Restrukturyzacji i Modernizacji Rolnictwa w Krakowie utrzymał w mocy decyzję organu I instancji o odmowie przyznania płatności dla gospodarstwa niskotowarowego. Powodem odmowy była okoliczność, że gospodarstwo rolne nie przekraczało powierzchni 1 ha użytków rolnych. W uzasadnieniu decyzji podano, że rozporządzenie Rady Ministrów z dnia 7 grudnia 2004 r. w sprawie szczegółowych warunków i trybu udzielania pomocy finansowej na wspieranie gospodarstw niskotowarowych ${ }^{2} \mathrm{ob}-$ jętej planem rozwoju obszarów wiejskich nie zawiera definicji gospodarstwa rolnego. W tym wypadku należy odwołać się do aktów wyższego (ogólniejszego) rzędu. Zdaniem organu, decydujące znaczenie ma ujęcie tych pojęć w Planie Rozwoju Obszarów Wiejskich. ${ }^{3}$ Zgodnie z pkt. 9.2.2 Planu, zawierającym wspólne definicje, definicja gospodarstwa rolnego przedstawia się następująco: gospodarstwo rolne jest to gospodarstwo rolne o powierzchni co najmniej 1 ha użytków rolnych. W związku z powyższym należy stwierdzić, że gospodarstwo o powierzchni mniejszej nie jest gospodarstwem rolnym w rozumieniu Planu Rozwoju Obszarów Wiejskich. Strona przeciwna podnosiła, że przepisy rozporządzenia Rady Ministrów z dnia 7 grudnia 2004 r. warunkują wspieranie gospodarstw niskotowarowych, ale określanych wielkością ekonomiczną to jest co najmniej 2 EJW i nie więcej niż 4 EJW, a nie wielkością użytków rolnych. A nadto w Planie Rozwoju Obszarów Wiejskich w części dotyczącej działania dotyczącego pomocy finansowej dla gospodarstw niskotowarowych, tj. w pkt 9. 4. brak jest definicji gospodarstwa rolnego opartej o kryterium obszarowe, brak zatem podstaw do stosowania definicji z pkt 9.2.2 Planu.

Wojewódzki Sąd Administracyjny w Krakowie rozpoznając powyższą sprawę nie podzielił poglądu zaprezentowanego przez organy administracyjne.

2 Dz.U. Nr 286, poz. 2870.

3 Obwieszczenie Ministra Rolnictwa i Rozwoju Wsi z dnia 15 listopada 2004 r. w sprawie planu rozwoju obszarów wiejskich M.P. Nr 56, poz. 958. 
Pomoc finansowa dla gospodarstw niskotowarowych, jako szczególna forma wsparcia finansowego dla Nowych Państw Członkowskich, wprowadzona została Traktatem Akcesyjnym dotyczącym warunków przystąpienia Republiki Czeskiej, Republiki Estońskiej, Republiki Cypryjskiej, Republiki Łotewskiej, Republiki Litewskiej, Republiki Węgierskiej, Republiki Malty, Rzeczypospolitej Polskiej, Republiki Słowenii i Republiki Słowackiej oraz dostosowań w Traktatach stanowiących podstawę Unii Europejskiej (Dz.Urz. UE L 03.236.33).

Traktatem Akcesyjnym zmienione zostało Rozporządzenie Rady (WE) nr 1257/1999 z dnia 17 maja 1999 r. w sprawie wsparcia rozwoju obszarów wiejskich z EFOGR, poprzez dodanie rozdziału IXa zatytułowanego Szczególne Środki dla Nowych Państw Członkowskich. W rozdziale tym art. 33b dotyczy wsparcia dla gospodarstw niskotowarowych $\mathrm{w}$ trakcie restrukturyzacji. Przepis art. 33b zawiera następującą definicję gospodarstwa niskotowarowego: „Dla celów niniejszego artykułu pojęcie ,gospodarstwa niskotowarowego" oznacza gospodarstwa, produkujące głównie na własne potrzeby, ale również sprzedające część swojej produkcji”.

W Polsce zadania oraz właściwość jednostek organizacyjnych i organów w zakresie wspierania rozwoju obszarów wiejskich, w dacie rozstrzygania wniosku, określała ustawa z dnia 28 listopada 2003 r. o wspieraniu rozwoju obszarów wiejskich ze środków pochodzących z Sekcji Gwarancji Europejskiego Funduszu Orientacji i Gwarancji Rolnej. ${ }^{4}$ Przepis art. 2 ust. 1 ustawy określał zasady opracowania projektu planu rozwoju obszarów wiejskich przez ministra właściwego do spraw rozwoju wsi. Zgodnie z art. 2 ust. 2, projekt planu zatwierdzała Rada Ministrów. Natomiast po przyjęciu planu przez Komisję Europejską: Rada Ministrów określała w drodze rozporządzenia szczegółowe warunki i tryb udzielania ...pomocy finansowej na działania objęte planem... mając na względzie zapewnienie prawidłowej realizacji planu i ustalenia dokonane z Komisją Europejską, a minister właściwy do spraw rozwoju wsi ogłaszał plan w drodze obwieszczenia. W oparciu o wskazaną delegację ustawową zostało wydane rozporządzenie Rady Ministrów z dnia 7 grudnia 2004 r. w sprawie szczegółowych warunków i trybu udzielania pomocy finansowej na wspieranie gospodarstw niskotowarowych objętej planem rozwoju obszarów wiejskich. ${ }^{5}$ Przepis $\S 3$ określał przesłanki jakie musi spełniać producent rolny będący osobą fizyczną, aby otrzymać płatność dla gospodarstwa niskotowarowego. Jedną z tych przesłanek jest prowadzenie działalności rolniczej w gospodarstwie będącym gospodarstwem niskotowarowym o wielkości ekonomicznej co najmniej 2 EJW (ESU) i nie więcej niż 4 EJW (ESU) w rozumieniu decyzji 85/377/EWG z dnia 7 czerwca 1985 r. ustanawiającą wspólnotową typologię gospodarstw rolnych. ${ }^{6}$ Powołane rozporządzenie nie zawiera innej definicji gospodarstwa rolnego, 
nie wprowadza kryterium wielkości powierzchni ani nie odsyła do stosowania definicji gospodarstwa rolnego z innego aktu prawnego. Również ustawa z dnia 28 listopada 2003 r. o wspieraniu rozwoju obszarów wiejskich... nie zawiera definicji gospodarstwa rolnego.

Natomiast definicja gospodarstwa rolnego zawarta jest w Planie Rozwoju Obszarów Wiejskich. Mianowicie w rozdziale 9 zatytułowanym „Opis Działań Planu” w pkt 9.2.2 zatytułowanym „Wspólne definicje” znajdują się definicje: działalności rolniczej, producenta rolnego, gospodarstwa rolnego i działki rolnej. Zgodnie z zawartą definicją ,gospodarstwo rolne" jest to gospodarstwo o powierzchni co najmniej 1 ha użytków rolnych. Natomiast w pkt 9.4 Planu dotyczącym działania 2, czyli wspieranie gospodarstw niskotowarowych brak jest definicji gospodarstwa rolnego, która posługiwałaby się kryterium powierzchni użytków rolnych, podczas gdy w innych częściach Planu dotyczących innych działań znajdują się definicje gospodarstw rolnych posługujące się kryterium powierzchni. Zdaniem organu II instancji, definicja gospodarstwa rolnego zamieszczona w definicjach wspólnych w pkt 9.2.2 Planu ma również zastosowanie do gospodarstwa niskotowarowego, a zdaniem skarżącego definicja ta nie powinna być stosowana, albowiem nie została zamieszczona w pkt. 9.4 dotyczącym wspierania gospodarstw niskotowarowych, czyli przedmiotem sporu stała się wykładnia Planu Rozwoju Obszarów Wiejskich.

Podczas gdy - zdaniem Wojewódzkiego Sądu Administracyjnego - zagadnieniem pierwszoplanowym wymagającym rozstrzygnięcia jest ustalenie charakteru prawnego Planu Rozwoju Obszarów Wiejskich, a tym samym, czy treść Planu może być podstawą prawną do rozstrzygnięć merytorycznych w formie decyzji administracyjnej, jednym słowem, czy Plan może być źródłem prawa, a zagadnieniem drugoplanowym jest wykładnia Planu.

Jak wskazano wyżej, projekt Planu został zatwierdzony przez Radę Ministrów, następnie Plan został przyjęty przez Komisję Europejską i ogłoszony w drodze obwieszczenia przez Ministra Rolnictwa i Rozwoju Wsi w Monitorze Polskim. Ustawa o wspieraniu rozwoju obszarów wiejskich ...wprowadzając w art. 2 ust. 2 wymóg zatwierdzenia projektu planu przez Radę Ministrów nie określiła formy prawnej, w jakiej miało nastąpić zatwierdzenie projektu planu. Zważywszy jednak na brak w ustawie delegacji do wydania rozporządzenia przez Radę Ministrów, a także mając na uwadze przyjęty w ustawie sposób ogłoszenia planu, należy przyjąć, że zatwierdzenie projektu planu ma formę uchwały Rady Ministrów.

Natomiast problematyka źródeł prawa uregulowana jest w rozdziale III Konstytucji Rzeczypospolitej Polskiej z dnia 2 kwietnia 1997 r. Na podstawie tego rozdziału Konstytucji wyróżnia się: źródła prawa zewnętrznego i źródła prawa wewnętrznego. Źródeł prawa zewnętrznego dotyczy przepis art. 87 Konstytucji, który stanowi ust. 1: Źródłami powszechnie obowiązującego prawa Rzeczypospolitej Polskiej są: 
Konstytucja, ustawy, ratyfikowane umowy międzynarodowe oraz rozporządzenia. Ust. 2: Źródłami powszechnie obowiązującego prawa Rzeczypospolitej Polskiej są na obszarze działania organów, które je ustanowiły, akty prawa miejscowego.

Z kolei źródeł prawa wewnętrznego dotyczy art. 93 Konstytucji. Zgodnie z art. 93 ust. 1: Uchwały Rady Ministrów oraz zarządzenia Prezesa Rady Ministrów i ministrów mają charakter wewnętrzny i obowiązują tylko jednostki organizacyjne podległe organowi wydającemu te akty. Ust. 2: Zarządzenia są wydawane tylko na podstawie ustawy. Nie mogą one stanowić podstawy decyzji wobec obywateli, osób prawnych oraz innych podmiotów. Ust. 3: Uchwały i zarządzenia podlegają kontroli co do ich zgodności z powszechnie obowiązującym prawem.

Zdaniem Sądu, Plan Rozwoju Obszarów Wiejskich, którego projekt zatwierdza Rada Ministrów w formie uchwały, stanowi źródło prawa wewnętrznego. Tym samym nie można z treści samego Planu wywodzić konieczności spełnienia określonych przesłanek i w oparciu o postanowienia Planu rozstrzygać w formie decyzji administracyjnej. Plan Rozwoju Obszarów Wiejskich nie jest bowiem źródłem prawa zewnętrznego. Adresatem Planu jest przede wszystkim Rada Ministrów, która wydając rozporządzenia w sprawie szczegółowych warunków i trybu udzielania, wstrzymywania, zawieszania, zwracania i zmniejszania pomocy finansowej na działania objęte planem (art. 3 ust. 2 pkt 1 ustawy) powinna kierować się treścią planu, tak aby wydane rozporządzenia zapewniały prawidłową realizację Planu. Dopiero rozporządzenie Rady Ministrów, które jest zewnętrznym źródłem prawa, może stanowić podstawę prawną wydania decyzji administracyjnej.

W rozpoznawanej sprawie podstawą prawną wydania decyzji jest rozporządzenie Rady Ministrów z dnia 7 grudnia 2004 r. w sprawie szczegółowych warunków i trybu udzielania pomocy finansowej na wspieranie gospodarstw niskotowarowych objętej planem rozwoju obszarów wiejskich. Rozporządzenie to, określając przesłanki uzyskania pomocy finansowej na wspieranie gospodarstw niskotowarowych, nie wprowadziło definicji gospodarstwa rolnego opartej o kryterium powierzchni użytków rolnych, natomiast wprowadziło definicję gospodarstwa opartą o wielkość ekonomiczną co najmniej 2 EJW (ESU) i nie więcej niż 4 EJW (ESU), zgodnie z postanowieniami Planu. Nadto zarówno ustawa o wspieraniu rozwoju obszarów wiejskich... zawierająca delegację ustawową do wydania przedmiotowego rozporządzenia Rady Ministrów, jak i art. 33b Rozporządzenia Rady (WE) 1257/1999 z dnia 17 maja 1999 r. w sprawie wsparcia rozwoju obszarów wiejskich... (wprowadzony Traktatem Akcesyjnym) dotyczący wsparcia dla gospodarstw niskotowarowych nie zawierają definicji gospodarstwa rolnego niskotowarowego opartej o kryterium powierzchni użytków rolnych.

W takim stanie prawnym przyjęcie, że pomoc finansowa dla gospodarstw niskotowarowych dotyczy tylko tych gospodarstw rolnych, które spełniają kryterium 
Wybrane zagadnienia z problematyki rozwoju obszarów wiejskich...

powierzchni co najmniej 1 ha użytków rolnych nie znajduje uzasadnienia, a jak wskazano wyżej takiego kryterium nie można wprost wywieść z Planu Rozwoju Obszarów Wiejskich i to nie z uwagi na dokonaną wykładnię Planu, ale z uwagi na charakter prawny Planu.

Rozważając charakter prawny Planu Rozwoju Obszarów Wiejskich, należy jeszcze podkreślić, że fakt zatwierdzenia Planu przez Komisję Europejską nie nadaje mu charakteru źródła prawa powszechnie obowiązującego, mogącego stanowić podstawę materialnoprawną wydania decyzji administracyjnej. Decyzja Komisji Europejskiej z dnia 6 września 2004 r. zatwierdzająca Plan Rozwoju Obszarów Wiejskich skierowana została wyłącznie do Rzeczypospolitej Polskiej jako państwa, a nie jej obywateli. Zgodnie z art. 249 zd. IV TWE, decyzja wiąże w całości adresatów do których jest kierowana. Należy wyraźnie zaznaczyć, że Plan Rozwoju Obszarów Wiejskich przez sam fakt zatwierdzenia decyzją Komisji Europejskiej nie stał się aktem prawa wspólnotowego, w związku z tym do analizy jego skutków stosować należało w pełni kryteria wynikające z polskiego porządku konstytucyjnego, zwłaszcza co do oceny pod kątem zakwalifikowania go do źródła prawa powszechnie obowiązującego, mogącego stanowić podstawę wydawania decyzji administracyjnych. Naczelny Sąd Administracyjny w wyroku z dnia 21 stycznia 2008 r. sygn. akt II GSK 287/07 oddalił skargę kasacyjną organu (analogicznie w wyroku z dnia 7 marca 2008 r. sygn. akt II GSK 336/07).

Przedmiotowe orzeczenia: Wojewódzkiego Sądu Administracyjnego w Krakowie i Naczelnego Sądu Administracyjnego, mimo że podjęte w konkretnej spornej sprawie, zachowują pewien walor ogólności poprzez rozważenie kwestii charakteru prawnego Planu Rozwoju Obszarów Wiejskich, z punktu widzenia źródeł prawa powszechnie obowiązującego, mogącego stanowić podstawę prawną wydania decyzji. A zważywszy, że wszelkie działania podejmowane w ramach rozwoju obszarów wiejskich podejmowane są w oparciu o Plan Rozwoju Obszarów Wiejskich, można również w innych sprawach spotkać się z podobnym problemem, w którym Plan będzie postrzegany jako podstawa prawna do wydawania decyzji administracyjnych.

Z kolei w sprawie sygn. akt III SA/Kr 276/06 organy administracyjne odmówiły przyznania pomocy finansowej na wspieranie gospodarstw niskotowarowych, wskazując na treść $§ 3$ pkt 3 a rozporządzenia Rady Ministrów z dnia 7 grudnia 2004 r. w sprawie szczegółowych warunków i trybu udzielania pomocy finansowej na wspieranie gospodarstw niskotowarowych objętej planem rozwoju obszarów wiejskich, ${ }^{7}$ zgodnie z którym pomoc może być przyznana producentowi rolnemu, będącemu osobą fizyczną, który prowadzi działalność rolniczą w gospodarstwie rolnym stanowiącym przedmiot odrębnej własności producenta rolnego albo jego małżonka, albo przedmiot ich współwłasności. Tym samym producent rolny, który jest 
współwłaścicielem gospodarstwa rolnego z innymi osobami fizycznymi nie spełnia tej przesłanki bez względu na źródło powstania współwłasności, jak również bez względu na związki rodzinne i pokrewieństwa zachodzące pomiędzy współwłaścicielami. W rozpoznawanej sprawie gospodarstwo rolne stanowiło współwłasność skarżącej i jej dzieci, a źródłem tej współwłasności było dziedziczenie na podstawie ustawy po zmarłym mężu i ojcu.

Rozpoznając przedmiotową sprawę, zasadne stało się pytanie, czy Rada Ministrów wprowadzając w rozporządzeniu z dnia 7 grudnia 2004 r. w sprawie szczegółowych warunków i trybu udzielania pomocy finansowej na wspieranie gospodarstw niskotowarowych objętej planem rozwoju obszarów wiejskich w $§ 3$ ust. 1 pkt 3 a wymóg, iż gospodarstwo rolne ma ,stanowić przedmiot odrębnej własności producenta rolnego albo jego małżonka, albo przedmiot ich współwłasności nie przekroczyła zakresu delegacji ustawowej i nie naruszyła podstawowych zasad konstytucyjnych, konsekwencją których jest zróżnicowanie w sposób nieuzasadniony sytuacji prawnej potencjalnych beneficjentów tej pomocy. Należy zaznaczyć, że stanowiący delegację ustawową przepis art. 3 ust. 2 ustawy z dnia 28 listopada 2003 r. o wspieraniu rozwoju obszarów wiejskich ze środków pochodzących z Sekcji Gwarancji Europejskiego Funduszu Orientacji i Gwarancji Rolnej nie zawiera kryterium pozwalającego na różnicowanie sytuacji prawnej beneficjentów będących osobami fizycznymi, podobnie jak wskazane wcześniej Rozporządzenie Rady (WE) Nr 1257/1999. Natomiast należy podkreślić, że w Planie Rozwoju Obszarów Wiejskich w pkt 9.4, tj. w części dotyczącej pomocy finansowej dla gospodarstw niskotowarowych znajduje się zapis, zgodnie z którym gospodarstwo rolne stanowić ma przedmiot odrębnej własności producenta albo jego małżonka. Tym samym rozważany przepis $\S 3$ ust. 1 pkt 3 a rozporządzenia Rady Ministrów z dnia 7 grudnia 2004 r. w stosunku do zapisów w Planie rozszerzył krąg podmiotów uprawnionych do otrzymania pomocy finansowej obejmując takie sytuacje, gdy gospodarstwo rolne stanowi współwłasność małżonków. Pomijając w tym miejscu wątpliwości dotyczące samego sformułowania współwłasność małżonków, a mianowicie, czy pojęcie to obejmuje również sytuację gdy gospodarstwo rolne stanowi przedmiot wspólności ustawowej małżonków, czy tylko gdy jest przedmiotem współwłasności ułamkowej, to zasadnicze pytanie dotyczy samych podstaw prawnych do wprowadzenia kryterium powodującego zróżnicowanie sytuacji prawnej beneficjentów. Czy zatem kryterium to pozostaje $\mathrm{w}$ racjonalnym związku z celem danej regulacji, czy waga interesu, któremu to różnicowanie ma służyć, pozostaje w odpowiedniej proporcji do wagi interesów, które zostaną naruszone w wyniku wprowadzonego zróżnicowania.

Zdaniem Wojewódzkiego Sądu Administracyjnego w Krakowie, przepis § 3 ust. 1 pkt 3 a rozporządzenia Rady Ministrów narusza podstawowe zasady i warto- 
ści konstytucyjne. Konstytucja Rzeczypospolitej Polskiej z dnia 2 kwietnia 1997 r. ${ }^{8}$ w przepisie art. 21ust. 1 wprowadza podstawową zasadę „Rzeczpospolita Polska chroni własność i prawo dziedziczenia.” Ochrona własności i prawa dziedziczenia stanowi jedną z podstawowych zasad ustroju gospodarczego Rzeczypospolitej. Własność w art. 21 Konstytucji została ujęta szeroko, bez różnicowania komu przysługuje prawo własności. Dla ochrony prawa własności jako jednego z podstawowych praw ekonomicznych istotne znaczenie ma art. 64 Konstytucji. Zgodnie z art. 64 ust. 1: Każdy ma prawo do własności, innych praw majątkowych oraz prawo dziedziczenia. Z kolei ust. 2 stanowi, że własność, inne prawa majątkowe oraz prawo dziedziczenia podlegają równej dla wszystkich ochronie prawnej. Własność może być ograniczona tylko w drodze ustawy i tylko w zakresie, w jakim nie narusza ona istoty prawa własności (ust. 3). Przepis art. 64 Konstytucji również ujmuje własność szeroko, zapewniając jej ochronę prawną, która oparta jest na równości.

Natomiast w art. 23 Konstytucji wprowadzono zasadę, iż ,,podstawą ustroju rolnego państwa jest gospodarstwo rodzinne". Wprowadzenie w akcie wykonawczym rozwiązania, które wyklucza z uzyskania pomocy finansowej producenta, który prowadzi działalność gospodarczą w gospodarstwie rolnym - stanowiącym w wyniku spadkobrania własność jego i jego dzieci, w tym małoletnich dzieci stanowi naruszenie art. 23 Konstytucji.

Zgodnie z przepisem art. 178 ust. 1 Konstytucji, sędziowie w sprawowaniu swojego urzędu są niezawiśli i podlegają tylko Konstytucji oraz ustawom. Zasada ta została powtórzona w przepisie art. 4 ustawy z dnia 25 lipca 2002 r. Prawo o ustroju sądów administracyjnych, ${ }^{9}$ zgodnie z którym sędziowie sądów administracyjnych w sprawowaniu swojego urzędu są niezawiśli i podlegają tylko Konstytucji oraz ustawom. Zatem Sąd Administracyjny może w konkretnej sprawie odmówić zastosowania przepisu aktu wykonawczego, jeżeli przepis ten narusza Konstytucję lub ustawy. W rozpoznawanej sprawie Sąd ocenił, że przepis $\S 3$ ust. 1 pkt 3 lit. „a” rozporządzenia Rady Ministrów z dnia 7 grudnia 2004 r. w sprawie szczegółowych warunków i trybu udzielania pomocy finansowej na wspieranie gospodarstw niskotowarowych objętej planem rozwoju obszarów wiejskich wydany został z naruszeniem delegacji ustawowej zawartej w art. 3 ust. 2 pkt 1, a w konsekwencji jest sprzeczny zarówno z ustawą, jak i Konstytucją. Taki przepis nie może tym samym stanowić podstawy prawnej wydania decyzji administracyjnej, stąd też Sąd odmówił jego zastosowania.

Naczelny Sąd Administracyjny, rozpoznając w przedmiotowej sprawie skargę kasacyjną wniesioną przez organ administracyjny, zawiesił postępowanie, albowiem Prezes Naczelnego Sądu Administracyjnego wystąpił do Trybunału Konstytucyjne- 
go o stwierdzenie, że $\S 3$ ust. 1 pkt 3 lit. a rozporządzenia Rady Ministrów w sprawie szczegółowych warunków i trybu udzielania pomocy finansowej na wspieranie gospodarstw niskotowarowych objętej planem rozwoju obszarów wiejskich jest niezgodny z delegacją ustawową, tj. art. 3 ust. 2 pkt 1 ustawy z dnia 28 listopada 2003 r. o wspierani rozwoju obszarów wiejskich ze środków pochodzących z Sekcji Gwarancji Europejskiego Funduszu Orientacji i Gwarancji Rolnej oraz art. 92 ust. 1 Konstytucji przez to, że ograniczył prawo do otrzymania płatności na wspieranie gospodarstw niskotowarowych wyłącznie do producentów rolnych prowadzących działalność rolniczą w gospodarstwie rolnym stanowiącym przedmiot odrębnej własności producenta rolnego albo jego małżonka, albo przedmiot ich wspólnej własności.

\section{Pomoc finansowa na zalesianie gruntów}

W sprawie o sygn. akt III SA/Kr 724/07 organy administracyjne odmówiły przyznania pomocy finansowej na zalesienie gruntów rolnych wskazując, że oświadczenie o wykonaniu zalesienia wraz $\mathrm{z}$ zaświadczeniem nadleśniczego zostało złożone z uchybieniem 14-dniowego terminu, określonego w § 9 ust. 2 rozporządzenia Rady Ministrów z dnia 11 sierpnia 2004 r. w sprawie szczegółowych warunków i trybu udzielania pomocy finansowej na zalesianie gruntów rolnych objętej planem rozwoju obszarów wiejskich. ${ }^{10}$ Zgodnie z $§ 9$ ust. 1 powołanego rozporządzenia, producent rolny w terminie 7 dni od dnia założenia uprawy leśnej informuje o tym fakcie na piśmie nadleśniczego, właściwego ze względu na miejsce położenia działek rolnych, na których została założona ta uprawa. Natomiast $\S 9$ ust. 2 stanowi, że producent rolny, w terminie 14 dni od dnia złożenia informacji o której mowa w ust. 1, jednakże nie później niż do dnia 31 maja: 1) roku, w którym zalesienie wykonano wiosną, albo 2) roku następującego po roku, w którym zalesienie wykonano jesienią - składa kierownikowi biura powiatowego Agencji oświadczenie o wykonaniu zalesienia zgodnie z planem zalesienia, do którego dołącza zaświadczenie nadleśniczego potwierdzające ten fakt.

Tym samym przepis $\S 9$ ust. 2 powołanego rozporządzenia nałożył na producenta obowiązek złożenia w organie I instancji oświadczenia o wykonaniu zalesienia wraz z zaświadczeniem, w terminie 14 dni od dnia zawiadomienia nadleśniczego, o założeniu uprawy leśnej. Przedmiotem wątpliwości, które pojawiają się na tle treści powyższego przepisu jest sposób określenia początku biegu 14-dniowego terminu do złożenia przez producenta oświadczenia wraz z zaświadczeniem. Mianowicie 14-dniowy termin nie biegł od daty otrzymania zaświadczenia wydanego przez nadleśniczego, ale od daty zawiadomienia nadleśniczego o założeniu uprawy leśnej. Tym samym zachowanie przez producenta terminu 14-dniowego do złożenia

Dz.U. Nr 187, poz. 1929. 
oświadczenia wraz z zaświadczeniem możliwe było tylko wówczas, gdy przed upływem tego terminu otrzymał zaświadczenie wydane przez nadleśniczego. W konsekwencji nadleśniczy po otrzymaniu informacji od producenta o założeniu uprawy leśnej powinien w terminie krótszym niż 14 dni sprawdzić, czy uprawa leśna została założona, wydać i doręczyć stosowne zaświadczenie; niedochowanie tego terminu przez nadleśniczego powoduje, że producent nie może zachować 14-dniowego terminu do złożenia oświadczenia wraz z zaświadczeniem. W konsekwencji zachowanie 14-dniowego terminu przez producenta rolnego było uzależnione od działania innego organu, orgnu właściwego w sprawie wydania zaświadczenia. Trzeba również zaznaczyć, że przepisy dotyczące udzielania pomocy finansowej na zalesianie nie wprowadzały szczególnych rozwiązań dotyczących trybu i terminu wydawania zaświadczeń czy też zasad ich doręczenia. Zastosowanie zatem miały przepisy kodeksu postępowania administracyjnego dotyczące zarówno wydawania zaświadczeń, jak i doręczania. Przepis art. $217 \S 3 \mathrm{kpa}$. stanowi, że zaświadczenie powinno być wydane bez zbędnej zwłoki, nie później jednak niż w terminie 7 dni. Natomiast odmowa wydania zaświadczenia lub zaświadczenia o żądanej treści następuje w formie postanowienia, na które przysługuje zażalenie. Wydanie przez organ zaświadczenia z przekroczeniem terminu 7 dniowego nie wpływa na treść zaświadczenia, a ponadto do wydania zaświadczenia może dojść dopiero w wyniku uwzględnienia zażalenia na postanowienie o odmowie wydania zaświadczenia lub zaświadczenia o żądanej treści, a więc w terminie znacznie dłuższym niż 14 dni. Wreszcie do zaświadczeń wydawanych przez organy administracji publicznej mają zastosowanie przepisy rozdziału 8 o doręczeniach. Brak bowiem podstaw prawnych, które pozwalałyby na wyłączenie przepisów kpa. o doręczeniach w przypadku zaświadczeń wydawanych przez nadleśniczego na podstawie rozporządzenia Rady Ministrów z dnia 11 sierpnia 2004 r. w sprawie szczegółowych warunków i trybu udzielania pomocy finansowej na zalesienie gruntów rolnych objętej planem rozwoju obszarów wiejskich.

Powyższe rozwiązania wynikające z kpa. wskazują, że od daty złożenia wniosku o wydanie zaświadczenia do daty otrzymania zaświadczenia może minąć więcej niż 14 dni, a organowi nie będzie można zarzucić naruszenia przepisów postępowania.

Przyjęcie tym samym w $\S 9$ ust. 2 powoływanego rozporządzenia Rady Ministrów, iż 14-dniowy termin do złożenia przez producenta rolnego oświadczenia wraz z zaświadczeniem o wykonaniu zalesienia biegnie od dnia złożenia informacji o założeniu uprawy leśnej jest nie do pogodzenia z zasadami kodeksu postępowania administracyjnego.

Ponadto, dla powyższych rozważań niezwykle istotnym zagadnieniem jest charakter prawny terminu 14-dniowego z $\S 9$ ust. 2 rozporządzenia, czy jest to termin 
procesowy, czy też termin materialnoprawny. W razie uchybienia terminu procesowego istnieje możliwość jego przywrócenia zgodnie z zasadami określonymi w rozdziale $10 \mathrm{kpa}$., natomiast termin materialnoprawny nie może być przywrócony. W rozważanym przypadku o charakterze prawnym 14 dniowego terminu do złożenia oświadczenia i zaświadczenia o wykonaniu zalesienia rozstrzygnął $§ 10$ powoływanego rozporządzenia Rady Ministrów z dnia 11 sierpnia 2004 r. Mianowicie $§ 10$ ust. 1 stanowił, że w przypadku gdy producent rolny nie złożył w terminie oświadczenia, o którym mowa w $\S 9$ ust. 2, kierownik biura powiatowego Agencji, w formie decyzji, odmawia przyznania płatności na zalesienie. A zatem niedochowanie tego terminu powoduje materialnoprawne skutki w postaci odmowy przyznania płatności na zalesienie, a zatem postępowanie wszczęte $\mathrm{z}$ wniosku strony o przyznanie płatności na zalesienie jest merytorycznie zakończone, a nie tylko procesowo.

Jak wynika z powyższych rozważań, zachowanie przez stronę 14 dniowego terminu do złożenia w organie I instancji oświadczenia wraz z zaświadczeniem o wykonaniu zalesienia uzależnione było od szybkości i sprawności działania innego organu, jakim jest nadleśnictwo właściwe do wydania zaświadczenia. Tym samym zainteresowana strona nie ma wpływu na dotrzymanie terminu, który bezpośrednio jej dotyczy. A nadto do przekroczenia terminu 14-dniowego może dojść w sytuacji, gdy organowi uprawnionemu do wydania zaświadczenia nie można postawić żadnego zarzutu dotyczącego naruszenia przepisów postępowania. Zważywszy, że termin ten ma charakter materialnoprawny, jego upływ powoduje, że strona traci prawo do nabycia pomocy finansowej na zalesienie.

Zdaniem Sądu, rozwiązanie przyjęte w $§ 9$ ust. 2 powoływanego rozporządzenia jest sprzeczne i narusza podstawowe zasady konstytucyjne, określone w Konstytucji Rzeczypospolitej Polskiej z dnia 2 kwietnia 1997 r. W szczególności narusza zasadę zaufania do państwa i tworzonego przez nie prawa. Zasadę tą wywodzi Trybunał Konstytucyjny z klauzuli demokratycznego państwa prawa zawartej w art. 2 Konstytucji, zgodnie z którym Rzeczpospolita Polska jest demokratycznym państwem prawnym, urzeczywistniającym zasady sprawiedliwości społecznej. Przyjęte w rozporządzeniu rozwiązanie narusza również konstytucyjną zasadę równości wobec prawa, zawartą w art. 32 Konstytucji. Zgodnie z przepisem art. 32 Konstytucji, Wszyscy są wobec prawa równi. Wszyscy mają prawo do równego traktowania przez władze publiczne. Rozwiązanie przyjęte w przepisie $\S 9$ ust. 2 powoływanego rozporządzenia powoduje, że sytuacja prawna osób starających się o skorzystanie z tej formy pomocy jest zróżnicowana w zależności od tego, czy inny organ zdąży wydać i doręczyć stosowne zaświadczenie przed upływem 14-dniowego terminu od złożenia informacji o założeniu uprawy leśnej.

Nadto, zdaniem Sądu, przyjęcie w $§ 9$ ust. 2 rozwiązania dotyczącego początku biegu 14-dniowego terminu do złożenia oświadczenia wraz z zaświadczeniem o wy- 
konaniu zalesienia powoduje, że podstawowy cel, jaki ma realizować pomoc finansowa na zalesienie gruntów rolnych, nie może być realizowany, mimo że wszystkie merytoryczne przesłanki wymagane do nabycia tej formy pomocy zostały spełnione.

W rozpoznawanej sprawie Sąd ocenił, że przepis $\S 9$ ust. 2 rozporządzenia Rady Ministrów z dnia 11 sierpnia 2004 r. w sprawie szczegółowych warunków i trybu udzielania pomocy finansowej na zalesianie gruntów rolnych objętej planem rozwoju obszarów wiejskich ${ }^{11}$ w zakresie określającym początek biegu 14-dniowego terminu wydany został z naruszeniem podstawowych zasad konstytucyjnych, tj. zasady zaufania wywodzonej z przepisu art. 2 Konstytucji oraz zasady równości wobec prawa wyrażonej w przepisie art. 32 Konstytucji. Taki przepis nie może tym samym stanowić podstawy prawnej wydania decyzji administracyjnej, stąd też Sąd odmówił jego zastosowania w zakresie określającym, iż 14-dniowy termin do złożenia oświadczenia wraz z zaświadczeniem o wykonaniu zalesienia rozpoczyna bieg od dnia złożenia informacji u nadleśniczego o wykonaniu zalesienia, a nie od dnia otrzymania zaświadczenia.

Warto zaznaczyć, że w nowym rozporządzeniu Ministra Rolnictwa i Rozwoju Wsi z dnia 18 czerwca 2007 r. w sprawie szczegółowych warunków i trybu przyznawania pomocy finansowej w ramach działania „Zalesianie gruntów rolnych oraz zalesianie innych gruntów niż rolne", objętego Programem Rozwoju Obszarów Wiejskich na lata 2007-2013 ${ }^{12}$, częściowo dostrzeżono podnoszony w orzecznictwie problem dotyczący określenia początku biegu terminu. Mianowicie w $\S 12$ ust. 2 przyjęto, że rolnik składa oświadczenie o wykonaniu zalesienia i dołącza do niego zaświadczenie nadleśniczego w terminie 21 dni od dnia wydania przez nadleśniczego tego zaświadczenia, jednakże nie później niż do dnia 20 czerwca. Przyjęte rozwiązanie nie jest jednak do końca poprawne, albowiem termin 21 dni powinien biec od dnia otrzymania zaświadczenia, a nie od dnia wydania zaświadczenia. Nie można bowiem wykluczyć sytuacji, gdy strona otrzyma zaświadczenie po upływie 21 dni od daty jego wydania, wówczas staniemy przed analogicznym problemem jak w wskazanym orzeczeniu.

\section{Ułatwianie startu młodym rolnikom}

Działanie w postaci ułatwiania startu młodym rolnikom aktualnie realizowane jest na podstawie ustawy z dnia 7 marca 2007 r. o wspieraniu rozwoju obszarów wiejskich z udziałem środków Europejskiego Funduszu Rolnego na rzecz Rozwoju Obszarów Wiejskich. ${ }^{13}$ Natomiast przed wejściem w życie wymienionej wyżej ustawy ta forma wsparcia realizowana była na podstawie ustawy z dnia 20 kwietnia 
2004 r. o Narodowym Planie Rozwoju w ramach Sektorowego Programu Operacyjnego „Restrukturyzacja i modernizacja sektora żywnościowego oraz rozwój obszarów wiejskich" w zakresie działania „Ułatwianie startu młodym rolnikom”. Ta forma wsparcia finansowego realizowana jest na podstawie umowy cywilnoprawnej zawieranej pomiędzy osobą ubiegającą się o dofinansowanie a organem ARiMR.

Zagadnieniem spornym była natomiast kwestia w jakiej formie prawnej następuje odrzucenie wniosku o przyznanie dofinansowania wyżej wymienionego projektu z uwagi na niespełnienie określonych przesłanek. W kwestii tej zarysowała się rozbieżność w orzecznictwie Naczelnego Sądu Administracyjnego. Mianowicie w wyroku z dnia 8 czerwca 2006 r. sygn. akt II GSK 63/06 NSA uznał, że przyznanie dofinansowania lub odmowa dofinansowania następuje w drodze decyzji administracyjnej. Natomiast odmienne stanowisko zostało zaprezentowane w wyroku NSA z dnia 20 września 2006 r. sygn. akt II GSK 95/06. Zdaniem składu orzekającego wydającego ten wyrok, przepisy ustawy o Narodowym Planie Rozwoju nie zawierają materialnoprawnej podstawy do wydawania decyzji administracyjnej w sprawach dotyczących przyznania dofinansowania projektu w zakresie działania „Ułatwianie startu młodym rolnikom”. Z uwagi na istniejące rozbieżności w orzecznictwie, w kolejnej sprawie sygn. akt II GPS 3/06 Naczelny Sąd Administracyjny przedstawił składowi siedmiu sędziów NSA do rozstrzygnięcia następujące zagadnienie prawne: „Czy rozstrzygnięcie odrzucające wniosek o przyznanie dofinansowania projektu na podstawie art. 26 ust. 2 ustawy z dnia 20 kwietnia 2004 r. o Narodowym Planie Rozwoju w ramach Sektorowego Programu Operacyjnego „Restrukturyzacja i modernizacja sektora żywnościowego oraz rozwój obszarów wiejskich 2004-2006” w zakresie działania „Ułatwianie startu młodym rolnikom” jest decyzją administracyjną czy aktem z zakresu administracji publicznej dotyczącym uprawnienia wynikającego z przepisu prawa (art. $3 \S 2$ pkt 1 i 4 p.p.s.a.)?" W dniu 22 lutego 2007 r. Naczelny Sąd Administracyjny w składzie siedmiu sędziów podjął następującą uchwałę: Odrzucenie wniosku, o którym mowa w art. 26 ust. 1 ustawy z dnia 20 kwietnia 2004 r. o Narodowym planie Rozwoju ${ }^{14}$ następuje $\mathrm{w}$ formie decyzji administracyjnej na podstawie art. 26 ust. 2 tej ustawy. W uzasadnieniu uchwały między innymi wskazano, że przepisy ustawy o Narodowym Planie Rozwoju wskazują na istnienie wyodrębnionych dwóch etapów postępowania w sprawach dotyczących dofinansowania z publicznych środków wspólnotowych projektów zgłaszanych w ramach sektorowych programów operacyjnych unormowanych osobno, w dwóch różnych ustępach art. 26 tej ustawy. Na pierwszy etap składa się postępowanie wszczynane na skutek wniosku podmiotu ubiegającego się o dofinansowanie z publicznych środków wspólnotowych projektu w ramach m.in. sektorowego programu operacyjnego. W tym etapie następuje rozpoznanie wniosku przez instytucję zarządzającą lub instytucję wdrażającą, stosownie do przyję- 
tego sytemu realizacji. Etap ten kończy się wydaniem rozstrzygnięcia na podstawie art. 26 ust. 2 ustawy. Dopiero po pozytywnym dla strony rozstrzygnięciu następuje drugi etap postępowania, którym jest zawarcie umowy określającej warunki dofinansowania projektu (art. 26 ust. 5 ustawy). Na istnienie dwóch etapów w ramach postępowania o dofinansowanie wskazują także przepisy rozporządzenia Ministra Rolnictwa i Rozwoju Wsi z dnia 8 września 2004 r. w sprawie Uzupełnienia Sektorowego Programu Operacyjnego „Restrukturyzacja i modernizacja sektora żywnościowego oraz rozwój obszarów wiejskich 2004-2006". ${ }^{15}$ Stosownie do tych przepisów wpierw ma miejsce zatwierdzenie wniosku składanego przez beneficjenta, a następnie podpisanie umowy o dofinansowanie.

Zdaniem składu siedmiu sędziów NSA, w świetle art. 26 ust. 2 ustawy o Narodowym Planie Rozwoju, rozstrzygnięcia podejmowane w pierwszym etapie przedstawionej wyżej złożonej procedury mają charakter indywidualnych rozstrzygnięć władczych i jednostronnych. Użyte przez ustawodawcę określenie ,przyznaje” dofinansowanie należy interpretować jako stworzenie podstawy prawnej do wydania przez ARiMR decyzji administracyjnej. W obowiązującym ustawodawstwie występują konstruowane w taki „,czasownikowy” sposób podstawy prawne do wydawania decyzji np. za pomocą zwrotów ,zezwala”, ,przydziela”, ,,potwierdza” czy „,wyraża zgodę”. Analogiczny charakter ma zwrot: organ ,przyznaje dofinansowanie”, z którego wynika kompetencja Agencji do wydawania decyzji administracyjnej w sprawie przyznania pomocy na podstawie art. 26 ust. 2 ustawy o NPR. Decyzja ta jest pozytywna albo negatywna (odrzucenie wniosku), tak jak w sytuacji objętej pytaniem prawnym. Decyzje wydawane na podstawie art. 26 ust. 2 ustawy o NPR mają charakter indywidualny i jednostronny. Natomiast władczość omawianej decyzji nie może być rozumiana w sposób tradycyjny, z nawiązaniem do przymusu państwowego. Cecha ta przejawia się w wyłączności skutków prawnych decyzji o przyznaniu dofinansowania. Wyłączność ta polega na tym, że umowy, o których mowa w art. 26 ust. 5 ustawy o NPR mogły być zawarte jedynie z osobami, którym Agencja przyznała dofinansowanie. Zawarcie umowy bez uprzedniej, pozytywnej decyzji byłoby niezgodne z ustawą. Ujmując rzecz od drugiej strony: decyzja administracyjna jest niezbędną przesłanką zawarcia umowy. Istnienie materialnej podstawy do rozstrzygnięcia sprawy decyzją administracyjną przesądza już o tym, że nie jest to akt z zakresu administracji publicznej, o którym stanowi art. $3 \S 2$ pkt 4 ustawy Prawo o postępowaniu przed sądami administracyjnymi.

Ustawa z dnia 7 marca 2007 r. o wspieraniu rozwoju obszarów wiejskich z udziałem środków Europejskiego Funduszu Rolnego na rzecz Rozwoju Obszarów Wiejskich obejmuje swym zakresem przedmiotowym znacznie szerszy katalog działań niż poprzedzająca ja ustawa z 28 listopada 2003 r. o wspieraniu rozwoju 
obszarów wiejskich. Wśród działań objętych ustawą z 2007 r. jest m.in. ułatwianie startu młodym rolnikom. Pomoc w ramach tego działania, jak i szeregu innych realizowana jest na podstawie umowy. Do postępowań w sprawach przyznania pomocy na podstawie umowy nie stosuje się przepisów kpa, $\mathrm{z}$ wyjątkiem przepisów dotyczących właściwości miejscowej organów, wyłączenia pracowników organu, doręczeń i wezwań (art. 22 ust. 2). Ustawodawca tym razem jednoznacznie rozstrzygnął, w jakiej formie następuje odmowa przyznania pomocy, jeżeli nie są spełnione warunki przyznania pomocy, a tym samym nie może dojść do zawarcia umowy. Mianowicie organ informuje wnioskodawcę, w formie pisemnej, o odmowie jej przyznania z podaniem przyczyn odmowy. W takim przypadku wnioskodawcy przysługuje prawo wniesienia do sądu administracyjnego skargi na zasadach i w trybie określonym dla aktów lub czynności, o których mowa w art. 3 § 2 pkt 4 ustawy z dnia 30 sierpnia 2002 r. Prawo o postępowaniu przed sądami administracyjnymi.

Tym samym na tle aktualnego stanu prawnego w sposób jednoznaczny rozstrzygnięta została kwestia przyznania pomocy na podstawie umowy, jak i forma prawna w jakiej organ może odmówić przyznania pomocy. Niewątpliwie istniejące na tym tle niedoskonałości legislacyjne, sygnalizowane i podniesione w orzecznictwie Naczelnego Sądu Administracyjnego, stały się bodźcem do jednoznacznego uregulowania rozważanego zagadnienia.

\section{Podmioty uprawnione do otrzymania płatności bezpośrednich w przypadku wspólnot gruntowych}

Szeroko określony krąg podmiotów uprawnionych do korzystania z płatności bezpośrednich, a także powszechne korzystanie $\mathrm{z}$ tej formy wsparcia finansowego spowodowało konieczność rozstrzygnięcia przez Sądy administracyjne takiego zagadnienia jak wskazanie podmiotu uprawnionego do otrzymania płatności bezpośrednich w przypadku wspólnot gruntowych.

Już na wstępie należy zaznaczyć, że w przedmiotowej sprawie jeszcze nie ukształtowało się jednolite orzecznictwo sądowe. $Z$ dotychczasowego nielicznego orzecznictwa Wojewódzkich Sądów Administracyjnych wynika, że w przedmiotowej sprawie prezentowane są dwa odmienne stanowiska, natomiast Naczelny Sąd Administracyjny jeszcze nie miał okazji do wypowiedzenia się w tej kwestii.

Zgodnie z art. 2 ust. 1 ustawy z dnia 18 grudnia 2003 r. o płatnościach bezpośrednich do gruntów rolnych ${ }^{16}$, Osobie fizycznej, osobie prawnej lub jednostce organizacyjnej nieposiadającej osobowości prawnej, będącej posiadaczem gospodarstwa rolnego, zwanej dalej ,producentem rolnym”, przysługują płatności na będące $\mathrm{w}$ jej posiadaniu grunty rolne utrzymywane w dobrej kulturze rolnej, przy zachowa-

Dz.U z 2004 r. Nr 6, poz. 40. 
niu wymogów ochrony środowiska, zwane dalej „gruntami rolnymi”. Warunkiem uzyskania płatności jest posiadanie przez producenta rolnego działek rolnych o łącznej powierzchni nie mniejszej niż 1 ha, które kwalifikują się do objęcia płatnościami, przy czym za działkę rolna uważa się zwarty obszar gruntu rolnego, na którym jest prowadzona jedna uprawa, o powierzchni nie mniejszej niż 0,1 ha, wchodzący w skład gospodarstwa rolnego.

W sprawie o sygn. akt IIISA/Kr914/05 (podobnie w sprawie o sygn. akt III SA/Kr 1046/05) o przyznanie jednolitej płatności obszarowej ubiegała się Spółka dla Zagospodarowania Wspólnoty Gruntowej, wpisana do ewidencji producentów zgodnie z ustawą z dnia 18 grudnia 2003 r. o krajowym systemie ewidencji producentów, ewidencji gospodarstw rolnych oraz ewidencji wniosków o przyznanie płatności. ${ }^{17}$ Organy administracyjne odmówiły przyznania płatności Spółce, wskazując w uzasadnieniu, że płatności mogą otrzymać uczestnicy wspólnoty gruntowej. Wojewódzki Sąd Administracyjny w Krakowie nie podzielił powyższego poglądu przyjmując, że beneficjentem płatności może być Spółka dla Zagospodarowania Wspólnoty Gruntowej. Odwołując się do przepisu art. 5 ust. 1 lit. b rozporządzenia Komisji (WE) Nr 2419/2001 nie można jednak ograniczać się do interpretacji wyłącznie powyższego przepisu, bez systemowego spojrzenia na całość regulacji zawartej w przedmiotowym rozporządzeniu. Tym bardziej, że określenie „obszar uprawy paszowej" pojawia się jeszcze w innych przepisach tego rozporządzenia. I tak w art. 34 powołanego rozporządzenia Komisji mowa jest o obliczaniu powierzchni paszowej określonego w art. 12 rozporządzenia (WE) nr 1254/1999, natomiast w art. 35 rozporządzenia Komisji mowa jest o obliczaniu powierzchni paszowej dla dopłat ekstensywnych zgodnie z art. 13 rozporządzenia (WE) nr 1254/1999.

Powoływane rozporządzenie (WE) nr 1254/1999 to rozporządzenie Rady (WE) z dnia 17 maja 1999 r. w sprawie wspólnej organizacji rynku wołowiny i cielęciny (Dz.Urz. UE L 99.160.21), które m.in. w rozdziale I reguluje problematykę płatności bezpośrednich funkcjonujących na tym rynku, w tym premii specjalnych, dla obliczenia której zgodnie z art. 12 należy m.in. ustalić obszar przeznaczony na pasze oraz premię ekstensywną uregulowaną w art. 13, który określa zasady ustalania obszaru przeznaczonego na pasze dla potrzeb tej premii. Stąd też należy zwrócić uwagę na treść sformułowania art. 5 ust. 1 lit b powoływanego rozporządzenia Komisji (WE) Nr 2419/2001, które brzmi ,,ust. 1. Dla celów niniejszego rozporządzenia: b) w przypadku gdy obszar uprawy paszowej jest użytkowany wspólnie, właściwe władze krajowe przyporządkowują go indywidualnym rolnikom proporcjonalnie do ich użytkowania lub prawa do użytkowania danego obszaru". Jak wskazano wyżej, zakres przedmiotowego rozporządzenia Komisji (WE) Nr 2419/2001 jest szeroki 
i dotyczy różnych systemów płatności bezpośrednich jakie funkcjonują w ustawodawstwie unijnym.

Natomiast w Polsce zgodnie z ustaleniami zawartymi w Traktacie Akcesyjnym (Dz.Urz. UE L 03.236.33) zastosowany został uproszczony system dopłat bezpośrednich. Mianowicie w rozporządzeniu Rady (WE) nr 1782/2003 z dnia 29 września 2003 r. ustanawiającym wspólne zasady dla systemów wsparcia bezpośredniego w ramach wspólnej polityki rolnej aktem prawnym regulującym problematykę wspólnot gruntowych jest ustawa z dnia 29 czerwca 1963 r. o zagospodarowaniu wspólnot gruntowych. ${ }^{18}$ Ustawa nie zawiera definicji sensu stricto wspólnoty gruntowej, a tylko w sposób taksatywny wylicza nieruchomości traktowane przez ustawodawcę jako wspólnoty. Nieruchomości rolne, leśne i obszary wodne wymienione w ustawie w art. 1 ust. 1 punkty od 1 do 7 tworzą wspólnoty gruntowe z mocy prawa. To ustawodawca określił, które nieruchomości w dacie wejścia w życie ustawy, czyli dnia 5 lipca 1963 r. uzyskały status wspólnoty gruntowej. Po tej dacie powstanie wspólnoty gruntowej było już niemożliwe z uwagi, iż w obowiązującym stanie prawnym nie ma i nie było regulacji prawnej dotyczącej wspólnot gruntowych. Również obecnie nie można powołać nowej wspólnoty na podstawie ustawy z dnia 29 czerwca 1963 r. o zagospodarowaniu wspólnot gruntowych.

Osobami uprawnionymi do udziału we wspólnocie gruntowej są osoby fizyczne lub prawne posiadające gospodarstwa rolne, jeżeli w ciągu ostatniego roku przed dniem wejścia w życie ustawy faktycznie korzystały z tej wspólnoty. Istotą tej wspólności jest uprawnienie do udziału we wspólnocie gruntowej w postaci korzystania z objętych nią gruntów, zgodnie z ich przeznaczeniem. Wspólnoty gruntowej nie możemy traktować jako jednej z form współwłasności, tj. współwłasności łącznej lub współwłasności ułamkowej z uwagi na odrębny charakter jaki został im nadany ustawą z dnia 29 czerwca 1963 r. Przede wszystkim art. 5 ust. 1 ustawy wprowadza ustawowy zakaz podziału wspólnot gruntowych, wspólnoty gruntowe nie mogą być dzielone pomiędzy uprawnionych do udziału w tych wspólnotach. Kolejna istotna cecha wspólnot gruntowych, różniąca ją od stosunków współwłasności, związana jest z możliwością reprezentowania wspólnoty na zewnątrz i działania w imieniu i na rzecz uczestników wspólnoty.

Zgodnie z art. 14 ustawy, do sprawowania zarządu nad wspólnotą do właściwego zagospodarowania gruntów wchodzących w skład wspólnoty istnieje obowiązek powołania spółki. Utworzenie spółki następuje w drodze uchwały powziętej większością głosów uprawnionych do udziału we wspólnocie przy obecności przynajmniej ich połowy. Członkami spółki są osoby uprawnione do udziału we wspólnogruntowych, Warszawa 1963; M. Ptaszyk, Spółki do zagospodarowania wspólnot gruntowych - sytuacja prawna, funkcjonowanie, perspektywy, Kraków 1989. 
cie gruntowej. Natomiast art. 25 ustawy określa, kiedy organ administracyjny może utworzyć spółkę przymusową. Spółka jest osobą prawną. Statut spółki określa miedzy innymi: prawa i obowiązki członków spółki, organy spółki, sposób ich powoływania i zakres działania. Zgodnie z art. 22 ustawy, to spółka jest uprawniona do wznoszenia i utrzymywania na wspólnocie gruntowej urządzeń potrzebnych dla osiągnięcia celów spółki.

Jak wynika z tej szczególnej regulacji, uczestnicy wspólnoty jako osoby fizyczne nie mają uprawnień do występowania w imieniu wspólnoty. Mogą to czynić jedynie poprzez spółkę, która jako osoba prawna może występować w imieniu uczestników wspólnoty. Spółka jest organem przymusowym i przynależność do niej następuje ipso iure, w momencie jej utworzenia. Kompetencje przyznane spółkom przez ustawę wyłączają indywidualne działanie w zakresie tych kompetencji przez samych uprawnionych. Tak więc to nie uczestnicy wspólnoty, lecz spółka jako osoba prawna jest uprawniona do podejmowania przed sądami czynności procesowych. Stąd też w przedmiotowej sprawie nieruchomości rolne stanowiące wspólnotę gruntową w rozumieniu ustawy z dnia 29 czerwca 1963 r. o zagospodarowaniu wspólnot gruntowych mogą być objęte płatnościami bezpośrednimi, jeżeli spełniona jest przesłanka dotycząca powierzchni działek rolnych i przesłanka utrzymywania w dobrej kulturze rolnej, przy zachowaniu wymogów ochrony środowiska. Natomiast o tym, jaki podmiot jest uprawniony do otrzymania płatności bezpośrednich z tytułu posiadania nieruchomości stanowiących wspólnotę gruntową, nie można rozstrzygać z pominięciem z tej szczególnej regulacji, jaką jest ustawa z dnia 29 czerwca 1963 r. o zagospodarowaniu wspólnot gruntowych. To z tej regulacji wynika, iż uczestnicy wspólnoty, mimo że są uprawnieni do korzystania z nieruchomości będących przedmiotem wspólnoty, równocześnie zostali pozbawieniu możliwości występowania w imieniu wspólnoty, jak i podejmowania jakichkolwiek czynności prawnych w stosunku do nieruchomości na rzecz obowiązkowo powoływanej spółki będącej osobą prawną.

Należy także zwrócić uwagę, że ustawa o płatnościach bezpośrednich do gruntów rolnych stanowiąc, że uprawnionym do ich otrzymania może być osoba prawna, nie wyłączyła żadnych z osób prawnych. Tym samym w przypadku osób prawnych będziemy spotykać się z pewną różnorodnością tych podmiotów wynikającą z różnorodnych aktów prawnych powołujących czy też określających ustrój prawny osób prawnych.

Natomiast Wojewódzki Sąd Administracyjny w Warszawie w wyroku z dnia 6 września 2006 r. sygn. akt IV SA/Wa 452/06 zajął odmienne stanowisko, przyjmując, że w przypadku wspólnoty gruntowej osoby uprawnione do korzystania z niej, a więc posiadacze gospodarstw rolnych, w przypadku składania wniosków o płatności obszarowe, winni dopisywać do posiadanych gruntów również powierzchnie 
wynikające $\mathrm{z}$ ich udziału ułamkowego w takich wspólnotach. W uzasadnieniu tego stanowiska wskazano, że wspólnota gruntowa jest - co do zasady - rodzajem współwłasności. A od dnia wejścia w życie ustawy z dnia 29 czerwca 1963 r. o zagospodarowaniu wspólnot gruntowych niemal wszystkie sprawy związane z statusem wspólnot gruntowych objęte zostały reżimem prawa administracyjnego. Podkreślono, że na gruncie niniejszej sprawy szczególnie należy wskazać na art. 9 ustawy, wg którego udziały we wspólnocie gruntowej określa się w idealnych (ułamkowych) częściach, a to prowadzi do wniosku, że w przypadku wspólnoty gruntowej osobami uprawnionymi do płatności obszarowych są posiadacze gospodarstw rolnych.

Problematyka wspólnot gruntowych pojawiła się również w sprawie sygn. akt II SA/Lu 534/07, a przedmiotem sprawy była kwestia wpisu do ewidencji producentów rolnych i nadania numeru identyfikacyjnego. Organ odmówił wpisu do ewidencji producentów Spółki dla Zagospodarowania Wspólnoty Gruntowej. W uzasadnieniu wskazano, że uprawnionymi do udziału we wspólnocie gruntowej są osoby fizyczne lub prawne posiadające gospodarstwo. Osoby uprawnione do udziału we wspólnocie tworzą spółkę do sprawowania zarządu nad wspólnotą i do właściwego zagospodarowania gruntów wchodzących w skład tej wspólnoty. Z powyższych regulacji organy wyciągnęły wniosek, że Spółka nie ma podstaw do ubiegania się o wpis do ewidencji producentów, a następnie o przyznanie płatności do gruntów rolnych, gdyż płatności przysługują ich faktycznym użytkownikom. Wojewódzki Sąd Administracyjny w Lublinie nie podzielił powyższego poglądu i uchylił zaskarżoną decyzję. W uzasadnieniu odwołano się do kompleksowej analizy przepisów ustawy z dnia 29 czerwca 1963 r. o zagospodarowaniu wspólnot gruntowych, wskazując, że uprawnienia poszczególnego uczestnika wspólnoty nie mogą sięgać dalej, niż to przewiduje statut oraz przepisy ustawy, a nadto uczestnicy mogą działać tylko w ramach utworzonej spółki. Tym samym bezpodstawne są twierdzenia organu, iż skarżąca Spółka sprawuje jedynie zarząd nad majątkiem wspólnym, a pożytki z tytułu użytkowania gruntów wspólnoty przypadają poszczególnym osobom.

W świetle powyższych orzeczeń Spółka do Zagospodarowania Wspólnoty Gruntowej może być wpisana do ewidencji producentów, a w dalszej konsekwencji może uzyskać dopłaty bezpośrednie.

Przedstawione orzeczenia sądów administracyjnych wskazują, że brak jest jednolitego stanowiska w kwestii podmiotu uprawnionego do otrzymania płatności bezpośrednich w przypadku gruntów stanowiących wspólnotę gruntową. Stąd też ta problematyka nadal oczekuje na ukształtowanie jednoznacznego stanowiska w orzecznictwie. 


\section{Wnioski}

Przedstawione wybrane orzeczenia sądów administracyjnych wskazują na zagadnienia sporne z zakresu problematyki rozwoju obszarów wiejskich, płatności bezpośrednich, które pojawiają się w praktyce w związku $\mathrm{z}$ realizacją tych form wsparcia finansowego. Jednak rolą orzecznictwa sądowego jest nie tylko dostrzeżenie, stwierdzenie pewnych niejasności czy też uchybień stanu prawnego, ale przede wszystkim rozstrzygnięcie konkretnej sprawy. Tym samym poprzez orzecznictwo sądowe następuje swoista weryfikacja, ocena obowiązującego stanu prawnego, z możliwością - w granicach przewidzianych przez prawo - kształtowania wykładni obowiązującego prawa, czy też podjęcia kroków mających na celu czy to eliminację danej normy prawnej jako podstawy rozstrzygnięcia w konkretnej sprawie, czy też eliminację tej normy z sytemu prawa.

I mimo że w polskim systemie prawa orzeczenia sądowe nie stanowią źródła prawa, to stanowią jednak istotny czynnik, który wpływa na rozwój prawa. Można sformułować taki pogląd, że orzecznictwo sądowe jest tym czynnikiem, który badając praktykę funkcjonującą na podstawie dotychczasowego stanu prawnego, może wskazywać ewentualne nowe kierunki rozwoju prawa, w tym również prawa rolnego. 


\section{Selected issues on the development of rural areas, direct payments in administrative court verdicts}

\section{Summary}

The article discusses a range of issues concerning rural development and direct payments which became the subject of administrative courts' rulings.

The courts' rulings presented in the paper considered the issues that appeared in the work of administrative bodies as a result of the realization of some forms of financial support, which later became the subject of the litigation between a party and a given body. One of such problems especially important for the issue of the development of rural areas was the problem of the legal character of the Plan for the Development of Rural Areas and the question whether the content of the Plan could be a legal basis for adjudicating in the form of an administrative decision or, to put it shortly, whether the Plan could be a source of the law. However, one of the courts has expressed an opinion that the Plan for the Development of Rural Areas, whose project is approved by the Council of Ministers in the form of a resolution, constitutes a source of internal law. Therefore one cannot infer the necessity of complying the specific conditions just from the content of the Plan and one cannot adjudicate in the form of an administrative decision, basing on the resolutions of the Plan. The Plan for the Development of Rural Areas is not a source of external law.

Courts judicature is therefore a peculiar instrument of evaluation of the binding legal condition, having the means - within the frames of the law - to shape its interpretation or to take steps either to eliminate a given legal norm as a basis for adjudicating the specific case, or to eliminate the norm from the system of the law. 